\title{
Geographic differences in the carapace shape of the crab Cyrtograpsus affinis (Decapoda: Varunidae) and its taxonomic implications
}

\author{
ANÍBAL H. LEZCANO ${ }^{1}$, ROLANDO GONZÁLEZ-JOSÉ ${ }^{1}$, EDUARDO D. SPIVAK ${ }^{2}$ \\ and FERNANDO G. DELLATORRE ${ }^{1,3}$ \\ ${ }^{1}$ Centro Nacional Patagónico, Consejo Nacional de Investigaciones Científicas y Técnicas, Boulevard Brown 2915, \\ Puerto Madryn (U9120ACD), Chubut, Argentina. E-mail: lezcano@cenpat.edu.ar \\ ${ }^{2}$ Universidad Nacional de Mar del Plata, Funes 3250 (B7602AYJ), Mar del Plata, Argentina. \\ ${ }^{3}$ Universidad Nacional de la Patagonia San Juan Bosco, Brown Boulevard s/n, Puerto Madryn (U9120ACF), \\ Chubut, Argentina.
}

SUMMARY: Cyrtograpsus genus was traditionally considered to be composed of three species: C. angulatus, C. altimanus and $C$. affinis. However, recent studies have found solid evidence suggesting that $C$. affinis and $C$. altimanus belong to a single species and hypothesize that the morphological differences which caused this misclassification could be related to different ecophenotypes or life stages. Here we report a geometric morphometrics study on the carapace shape of Cyrtograpsus specimens from the Río de la Plata estuary $\left(36^{\circ} \mathrm{S}\right)$ and the Nuevo Gulf $\left(42.75^{\circ} \mathrm{S}\right)$, testing for shape differences between different sizes (allometry) in the two environments. We found that previous morphological descriptions of the two species were associated with different sizes of a continuous, statistically significant allometric shape variation, concluding that $C$. affinis is a junior synonym of $C$. altimanus. We also found significant differences in the carapace shape between estuarine and marine environments, suggesting an effect of the environmental variables on carapace shape and a potential adaptive value of this trait.

Keywords: Cyrtograpsus altimanus, allometry, geometric morphometrics, Río de la Plata estuary, Nuevo Gulf, local adaptations, contrasting habitats.

RESUMEN: DIFERENCIAS GEOGRÁFICAS EN LA FORMA DEL CAPARAZÓN DEL CANGREJO CYRTOGRAPSUS AFFINIS (DECAPODA: VARUNIDAE) Y SUS IMPLICACIONES TAXONÓMICAS. - El género Cyrtograpsus fue tradicionalmente considerado como formado por tres especies: C. angulatus, $C$. altimanus y $C$. affinis. Trabajos recientes reportan sólida evidencia que sugiere que $C$. altimanus y $C$. affinis pertenecen a una única especie y proponen que las formas que originaron esta clasificación errónea pueden corresponderse con diferentes ecofenotipos o estadios sucesivos del ciclo de vida de una misma especie. Este trabajo presenta un estudio de morfometría geométrica sobre la forma del caparazón de especímenes del género Cyrtograpsus provenientes del estuario del Río de la Plata $\left(36^{\circ} \mathrm{S}\right)$ y del golfo Nuevo $\left(42.75^{\circ} \mathrm{S}\right)$, en el que se prueban las diferencias en la forma del caparazón relativas al tamaño (alometría) y a los distintos ambientes. Nuestros resultados muestran que las descripciones morfológicas previas de ambas especies están asociadas a diferentes regiones de una variación alométrica continua y estadísticamente significativa, y nos permite concluir que $C$. affinis es un sinónimo juvenil de $C$. altimanus. Además encontramos diferencias significativas en la forma del caparazón entre especímenes provenientes del ambiente estuárico y el marino, lo cual sugiere un efecto de ciertas variables ambientales sobre la forma del caparazón y un potencial valor adaptativo de esta característica.

Palabras clave: Cyrtograpsus altimanus, alometría, morfometría geométrica, estuario del Río de la Plata, golfo Nuevo, adaptaciones locales, hábitats contrastantes. 


\section{INTRODUCTION}

Morphology has played a central role in species definition, and different forms have usually been defined as species in the absence of intermediate linking forms (Mallet 2005). The understanding of morphological variation and its spatial structure has been of crucial importance to answer fundamental questions in evolutionary biology, including the relationship between genotype and phenotype (Hopkins and Thurman 2010). Different selective pressures can generate and maintain different phenotypes, and morphological analyses are also useful to show those adaptive differences. However, some geographic variations acting upon morphology, reproductive patterns, growth rates and mortality are not always consistent with genetic variation. In some situations this variation is related to phenotypic plasticity as a result of different environmental conditions (Orensanz et al. 1991, Cadrin 2000). In marine benthic invertebrates, planktonic dispersal is considered to play a key role in homogenizing gene frequencies, and lack of larval exchange is thought to promote differentiation and increase the genetic structure and morphological differences between distant populations (Levin 2006).

Carapace shape has been used as a basic tool in crab systematics at species level (e.g. Rathbun 1918), but has also had ecological (Giri and Loy 2008, Sardà et al. 2005) and fishery-related significance (Cadrin 2000, Chang and Hsu 2004). Usually, carapace shape has been estimated through curvatures or pairwise comparison of linear measurements (Brian et al. 2006) and only a few studies have focused on the evaluation of its allometric changes (Huber 1985, Spivak and Schubart 2003, Botello and Alvarez 2006, Costa and SoaresGomes 2008). This is partly because classic morphometrics fails to separate size from shape variation (see Rohlf and Bookstein 1987). Allometry describes how an organism changes in shape and proportion as it grows (Peters 1983). Since the pioneering works of Huxley (1932) and Teissier (1960), it has been extensively reported in decapods and has usually been estimated by analyzing the relationship between the size of a structure (in crabs the chelae or abdomen) and the total size of the specimen (in crabs the carapace width or length). Three different types of size-shape relationship should be distinguished: ontogenetic, static, and evolutionary allometry (Cheverud 1982, Klingenberg 1996). Ontogenic relationships are the type that have been studied most and deal with covariation between characters during growth (Klingenberg 1996). This type of allometry is usually an important source of carapace shape variation and is reflected by the existence of many cases of junior synonymy (Santana and Tavares 2010, Osawa and McLaughlin 2010) resulting from the initial description of juvenile and adult forms as different species.

The field of morphometrics has undergone a revolution in which traditional approaches based on the sta- tistical analysis of sets of inter-landmark distances have been replaced by geometric morphometrics methods (Rohlf and Marcus 1993). Geometric morphometrics methods capture shape using the Cartesian coordinates of homologous landmarks after specimen displacement, orientation and size have been removed from the data. These approaches make it possible to analyze the covariation of shape and other variables (e.g. size) as an integral part of organism biology (Adams 1999). From a methodological viewpoint, Procrustes-based geometric morphometry of landmark data is an ideal tool for analyzing allometry for two reasons (Bookstein 1991): i) landmarks can be used as the carrier of biological hypotheses of different morphogenetic units, and their patterns of variation can be analyzed in isolated as well as pooled data sets; ii) this method is based on the operational separation of size and shape, which provides a surprisingly high analytical resolution in questions of allometry (Bookstein 1991, 1996, Rosas and Bastir 2004). In addition, this method generates a set of shape variables that can be used for statistical hypothesis testing, and provides a way of visually describing patterns of shape differences in the data (Adams 1999). Thus, shape differences between local populations of the same species can be reliably examined by using a global approach to shape analysis through geometric morphometrics (Aldrich 1993). There are several applications of geometric morphometrics methods to the shape of different crab structures, including the analysis of variation between sexes and among allopatric and sympatric populations, and the evaluation of geographic and gender differences and population structure (Giri and Loy 2008, Rufino et al. 2006, Silva et al. 2010).

Cyrtograpsus (Decapoda, Varunidae; sensu Schubart et al. 2000, Schubart et al. 2002) is an endemic South American genus (Rathbun 1918) with three previously recognized members that inhabit temperate marine and brackish waters: $C$. angulatus (Dana, 1851), C. altimanus (Rathbun, 1914), and C. affinis (Dana, 1851). C. angulatus is the largest (maximum carapace width, $\mathrm{MCW}=61 \mathrm{~mm}$; Leal and Barón, pers. comm.) and most intensely studied member of the genus (see Méndez Casariego et al. 2008, Daleo et al. 2009 and references therein); it has a bioceanic distribution and in the southwestern Atlantic it is found from Río de Janeiro (Brazil) to Santa Cruz province (Argentina) (Spivak 1997). C. altimanus (MCW=25 $\mathrm{mm}$; Spivak and Schubart 2003) is reported to occur from Río Grande do Sul (Brazil) to northern Patagonian gulfs (Argentina) (Spivak 1997, Silva 2009). Both species can coexist in a wide range of habitats, from intertidal to shallow subtidal and from soft (muddy) to rocky bottoms in marine or estuarine areas (Spivak 1999). Their feeding habits are omnivorous, with a predominance of benthic microalgae (Martinetto et al. 2007, Silva 2009). The smallest (MCW=12.1 mm) and least studied species of the genus, $C$. affinis (Spivak and Schubart 2003), ranges from Cape St. Roque (Bra- 
TABLE 1. - Sample composition. n: sample size and CWR: carapace width range (linear measurement in mm between the fourth lateral teeth).

\begin{tabular}{lccccc}
\hline Sampling location & Geographic position & Sampling dates & $\mathrm{n}$ & CWR & Labels \\
\hline Nuevo Gulf & $42^{\circ} 45^{\prime} \mathrm{S}, 65^{\circ} 00^{\prime} \mathrm{W}$ & April 13 to 28, 2005 & 137 & $1.51-27.76$ & "Madryn” \\
Río de la Plata estuary & $35^{\circ} 07^{\prime} \mathrm{S}, 56^{\circ} 02^{\prime} \mathrm{W}$ & November 19, 1997 & 39 & $5.61-11.31$ & "Spivak 01" \\
& $36^{\circ} 05^{\prime} \mathrm{S}, 56^{\circ} 37^{\prime} \mathrm{W}$ & March 9, 1998 & 109 & $4.26-9.54$ & "Spivak 05" \\
\hline
\end{tabular}

zil) to northern Patagonian gulfs, but it has only been found abundantly in sub-littoral environments near the Río de la Plata estuary (Spivak 1997, Spivak and Schubart 2003). These three species also differ in carapace shape (Rathbun 1918, Boschi 1964): roughly hexagonal with prominent anterolateral marginal teeth in $C$. angulatus, rounded with small teeth in $C$. altimanus and approximately square, a little broader than longer, with three smaller lateral teeth in $C$. affinis.

Recent comparisons based on molecular genetics and traditional morphometrics analyses support the hypothesis that $C$. affinis and $C$. altimanus "represent different ecophenotypes or life stages of the same species" (Spivak and Schubart 2003). Furthermore, morphological comparison of the first larval stages (Spivak and Cuesta 2000) and the gastric mill ossicles (Huespe et al. 2008) found no differences between the species; hence, at present $C$. affinis and $C$. altimanus are considered to be the same species (Cyrtograpsus affinis Dana, 1851). The aim of this paper is to test the suggestions of Spivak and Schubart (2003) on the basis of the allometric and geographic differences in carapace shape in specimens from the Río de la Plata estuary and the Nuevo Gulf. Specifically, the following null hypothesis will be tested: 1) changes in carapace shape are not related to variations in the size of the specimens, and 2) shape variations between geographic locations do not persist once allometric variation is statistically removed.

\section{MATERIALS AND METHODS}

\section{Study sites}

Nuevo Gulf $\left(42^{\circ} 45^{\prime} \mathrm{S}, 65^{\circ} \mathrm{W}\right)$ is an elliptical basin communicated with the southwestern Atlantic ocean through a $17-\mathrm{km}$-wide strait. Its maximum depth is 184 $\mathrm{m}$ and it is more than $110 \mathrm{~m}$ deeper than the surrounding continental shelf (Mouzo et al. 1978). The bottoms are characterized by large extensions of sandy, gravel and limestone seabeds (Parker et al. 1997). The hydrographic conditions are distinguished by seasonal fluctuations in temperature (between $8^{\circ} \mathrm{C}$ and $18^{\circ} \mathrm{C}$ ) and a constant salinity, near to 34 psu (Rivas and Ripa 1989). The Río de la Plata is an extensive and shallow coastal plain estuary in the western south Atlantic $\left(35^{\circ} 20^{\prime} \mathrm{S}\right.$, $\left.56^{\circ} 36^{\prime} \mathrm{W}\right)$, between Argentina and Uruguay. The main characteristics of the estuary are the large area that it covers and the occurrence of a quasi-permanent salt wedge, which generates bottom and surface salinity fronts (Giberto et al. 2004). Temperature ranges between $10^{\circ} \mathrm{C}$ and $24^{\circ} \mathrm{C}$ (Spivak 1997) and salinity ranges between approximately 0 and 30 (Guerrero et al. 1997). The average length is $300 \mathrm{~km}$ and the width varies between 40 and $200 \mathrm{~km}$. It has an average depth of 5 to $25 \mathrm{~m}$ and a tidal range of $1 \mathrm{~m}$, with the bottoms dominated by fine sediment and mud (Giberto et al. 2004).

\section{Sample collection}

A total of 285 crabs belonging to the genus Cyrtograpsus were captured: 137 specimens were collected in Nuevo Gulf on a muddy bottom at $18 \mathrm{~m}$ depth. They were initially identified as $C$. altimanus because the adult specimens captured matched the morphological traits reported for this species (see Boschi et al. 1992) and the sampling location was south of the distribution range reported for $C$. affinis (see Spivak 1997). Nevertheless, carapace width and shape was highly variable. This sample will be called "Madryn" hereinafter. In addition, 148 specimens identified initially as $C$. affinis were collected at two sites of the Río de la Plata estuary and labeled "Spivak 01" (10 m depth) and "Spivak 05" (13 $\mathrm{m}$ depth). The sample information is summarized in Table 1.

\section{Sample processing and image analysis}

The pereiopods were removed and the specimen was submerged in water on a Petri dish in order to minimize the light reflection. Carapaces were photographed in dorsal view with a digital camera (Canon Power Shot A510, 3.2 Megapixel), setting the picture plane parallel to its coronal plane (Fig. 1). Among the distortions that can cause artificial changes in shape, parallax distortion is the most frequent. This distortion can lead to a considerable skew in the data when the specimens are set near the borders of the picture's frame. To avoid parallax distortions, all photographs were taken setting the specimens in the centre of the image, with most of the image margins not occupied by the carapaces. Smaller specimens (ranging from 1.5 to $10 \mathrm{~mm}$ carapace width) were photographed under a binocular microscope with $6 \times, 12 \times$ and $25 \times$ magnification.

Fifteen landmarks and semi-landmarks were digitized using the tpsDig and tpsUtil software (Rohlf $2004 \mathrm{a}, \mathrm{c})$ on the left side of each carapace, assuming bilateral symmetry. Landmarks and semi-landmarks (Bookstein 1991) were chosen considering their homology in all specimens and their ability to capture the general shape of the carapace. Also, these landmarks and semi-landmarks satisfied the statistical 


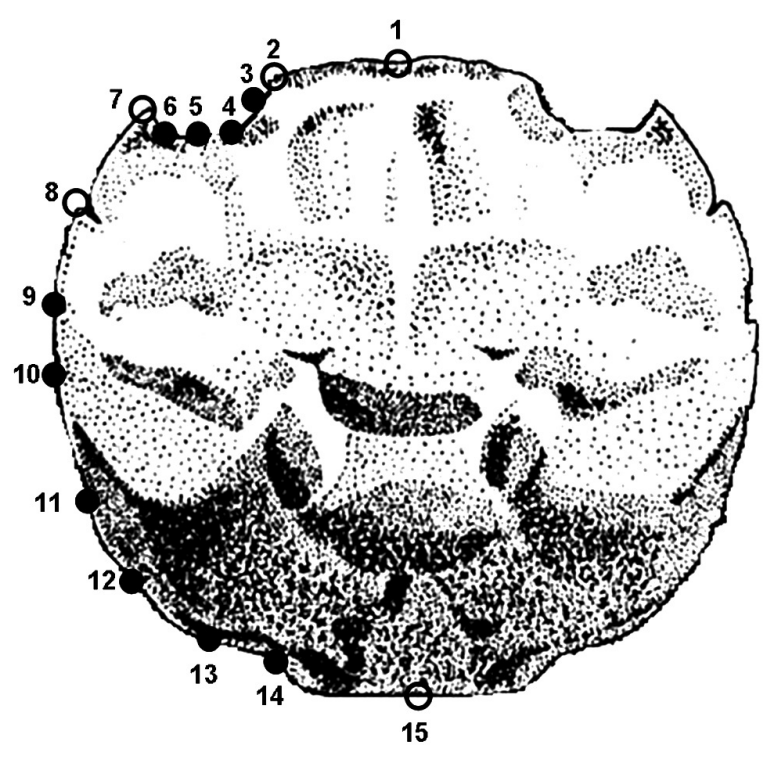

FIG. 1. - Landmarks configurations on the Cyrtograpsus carapace. Empty and full circles represent anatomical landmarks and semilandmarks, respectively. Landmarks 1 and 15 marks the anterior and posterior edge of the carapace, respectively; landmarks 2 and 7 are located on the internal and external border of the ocular depression, respectively; and landmark 8 indicates the first lateral teeth. Semilandmarks described the general contour of the carapace. Figure adapted from Boschi et al., 1992.

restrictions associated with geometric morphometrics methods (Rufino et al. 2006). The coordinates of semilandmarks were aligned by means of the sliding semilandmark method implemented in the tpsRelw software (Rohlf 2004b) and discussed by Perez et al. (2006) and Sheets et al. (2006). The semi-landmark points are slid along the outline curve in order to minimize the bending energy of the configurations (Gunz et al. 2005). Landmark and sliding semi-landmark configurations (landmark configurations hereinafter) can be seen in Figure 1.

All photos included a grid of known dimensions and were scaled using the scaling procedure implemented in the tpsDig software (Rohlf 2004a). On each landmark configuration the centroid was defined as the point in the centre of the configuration that minimizes the sum of squares (Sneath 1967). Centroid size was computed as the square root of the sum of the squares of the distances from all landmark configurations to their centroid, using the tpsRelw software (Rohlf 2004b). In order to avoid any deviation of centroid size from linearity and to scale all values in the comparisons, we used the logarithm in base 10 of the centroid size ( $\log$ centroid size from now on) that is considered as an unbiased estimator of size (Bookstein 1991). The use of log-transformed centroid size was also suggested by Klingenberg (2008) for ontogenetic studies including very early, small stages in which shape change is often concentrated disproportionately.

Landmark configurations were optimally aligned using a generalized Procrustes analysis to remove the effects of translation, rotation and scale (Rohlf and
Slice 1990, Rohlf 1999). After superimposition, each landmark configuration corresponds to a single point in a non-Euclidean multidimensional space known as Kendall's shape space (Kendall 1981, 1984). This space has $2 p-4$ dimensions, where $p$ is the number of twodimensional landmarks and semi-landmarks. Because of the difficulty in performing standard multivariate statistics in non-Euclidean space, each data point is then projected into a Euclidean space (also of $2 p-4$ dimensions) tangential to a reference point (usually the mean) in the shape space (Kent 1994, Rohlf 1999). Since shape data derived from Procrustes superimposition lie in a nonlinear, hyper-hemispherical shape space (Slice 2001), common statistical methods based on linearity can only be performed when the data is projected onto a Euclidean (linear) tangent space (Rohlf 1996). This approach of utilizing an orthogonal projection from the Procrustes hyper-hemisphere to tangent space is thought to yield the necessary linearization of curved distances in shape space (Bookstein 1991, Dryden and Mardia 1998, Slice 2001). A criterion for the reliability of statistical analysis is provided by a strong correlation between Procrustes and tangent space distances. In the present study, this correlation was computed using the tpsSmall software (Rohlf 1998) and was very strong and highly significant (correlation: 1.00; $P<0.001$ ). Therefore, the coordinates of the superimposed landmarks and semi-landmarks can be used in multivariate statistical analyses to address a wide range of biological questions (e.g. Klingenberg 2010). Multivariate descriptions of the data in the tangent space (the shape variables) can be generated through a variety of methods (Rohlf 1999). Here we use the thin-plate spline approach, which decomposes the data into two components of uniform shape change (known as uniforms scores) and $2 p-6$ components (known as partial warp scores) of non-uniform shape change (Bookstein 1991, 1996, Rohlf 1993). Uniform scores describe differences that affect all parts of the carapace equally (global differences), and partial warp scores describe localized departures from the average carapace map. Shape variation is described as the difference of each individual from a reference, after translation, rotation and scaling of all individuals and all homologous landmarks and semi-landmarks are superimposed. Each individual is represented in this Bookstein metaphor by its partial warp scores, which depict each individual's contribution to the grid deformation defined by them. The fifteen landmarks and semi-landmarks on the carapace led to 24 partial warp scores and 2 uniform scores for each sample.

\section{Statistical analysis}

\section{Carapace shape allometry}

Multivariate regression of shape (the aligned coordinates) on Log centroid size (carapace size) was performed using the MorphoJ software (Klingenberg 2011). The statistical significance of the regression was 


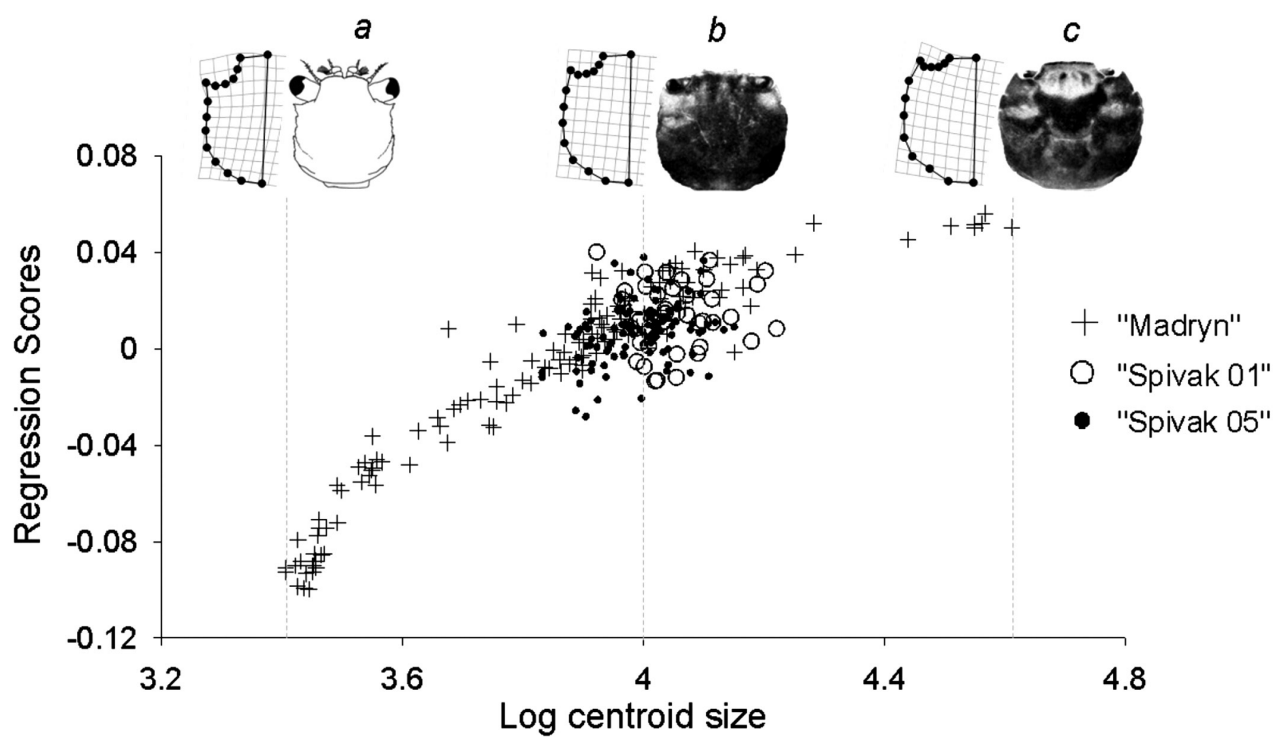

FIG. 2. - Scatterplot of the regression scores (carapace shape) versus the Log centroid size (carapace size). Drawings are those reported in literature describing $C$. affinis first juvenile instar ( $a$, Spivak and Cuesta 2000) and adult ( $b$, Rathbun, 1918), and $C$. altimanus adult ( $c$, Rathbun, 1918). The thin-plate spline deformation plots show the carapace shape corresponding to 3.4, 4 and 4.6 Log centroid size, respectively.

tested with permutation test against the null hypothesis of independence (Good 2000). The regression routine in MorphoJ computes a regression score for each specimen (Drake and Klingenberg 2008). The vectors of regression coefficients from this analysis can be visualized as shape change per unit of size increase. The scatterplot of the regression scores against the Log centroid size was made as it provides a graphical means to examine the strength of association between shape and size (Drake and Klingenberg 2008).

\section{Shape differences between geographic locations}

Two different approaches were used to assess geographic differences in shape:

a) Multivariate analysis of variance (MANOVA; Sokal and Rohlf 1995) was used to test the differences in shape variables (partial warp scores and uniform scores) between sampling locations. Post hoc comparisons were tested by means of a Newman-Keuls test. Alternatively, a permutational multivariate analysis of variance (PERMANOVA; Anderson et al. 2004) was performed using shape variables as the dependent variable and location as the independent variable. In order to generate a balanced design with 137 specimens per sample, the two estuary samples were pooled, thus achieving a new sample size of 148 individuals. Then, 11 specimens were randomly removed from the pooled sample in order to achieve the sample size of 137 required for a balanced PERMANOVA (Anderson 2001, Tracey et al. 2006).

b) In order to generate allometry-free shape variables, a multivariate regression of shape variables on Log centroid size was fitted to a polynomial model $\left(r^{2}=0.845\right.$ and $\left.P<0.01\right)$. This model was selected because of the lack of any a priori functional relationship between size and shape. Residuals of the regression model were considered as allometry-free shape variables (Webber and Hunda 2007, Hopkins and Webster 2009). MANOVA and PERMANOVA tests were performed as described above in order to compare the allometry-free variables.

To represent the major trends in shape differences (with and without the allometric effect), shape variables were transformed to a Euclidean distance dissimilarity matrix and the two corresponding non-metric multidimensional scaling ordination plots were obtained.

\section{RESULTS}

\section{Carapace shape allometry}

The multivariate regression of shape on carapace size was highly significant after 10000 permutations $(P<0.001)$ and allometry accounted for $41.76 \%$ of the total variation in carapace shape. The changes in carapace shape during growth are represented in the scatterplot shown in Figure 2. Shape changes along the size axis are gradual, without any evident discontinuity. The rate of shape changes relative to size was higher in smaller specimens, decreases with size and there were no dramatic shape changes in specimens with Log centroid size values higher than 4.3 (carapace width greater than approximately $12 \mathrm{~mm}$ ) (Fig. 2).

\section{Shape differences between geographic locations}

The differences between sampling locations were confirmed in both shape variables and allometry-free shape variables. The MANOVA and PERMANOVA tests performed on both datasets yielded significant differences (Table 2). The post hoc pairwise comparisons 
TABLE 2. - Statistical analyses to test for shape differences between sampling locations.

\begin{tabular}{|c|c|c|c|c|c|}
\hline & \multicolumn{3}{|c|}{ MANOVA } & \multicolumn{2}{|c|}{ PERMANOVA } \\
\hline & Wilk's $\lambda$ & $\mathrm{F}$ & $P$ & $\mathrm{~F}$ & $P$ \\
\hline Shape variables (partial warps and uniforms scores) & 0.2974 & 13.90 & $<0.001$ & 29.57 & $<0.001$ \\
\hline Allometry-free shape variables $(*)$ & 0.0549 & 54.48 & $<0.001$ & 32.59 & $<0.001$ \\
\hline
\end{tabular}

(*) Allometric effects were removed by using the residuals of a polynomial regression of shape variables (partial warps and uniforms scores) on Log centroid size.

were significant between "Madryn" and both estuary samples, and not significant between samples within the estuary.

Despite the significant shape differences found between estuarine and gulf specimens, this is not clearly visualized in the non-metric multidimensional scaling ordination computed on both datasets (shape variables and allometry-free shape variables; Figure $3 \mathrm{a}$ and $\mathrm{b}$, respectively).
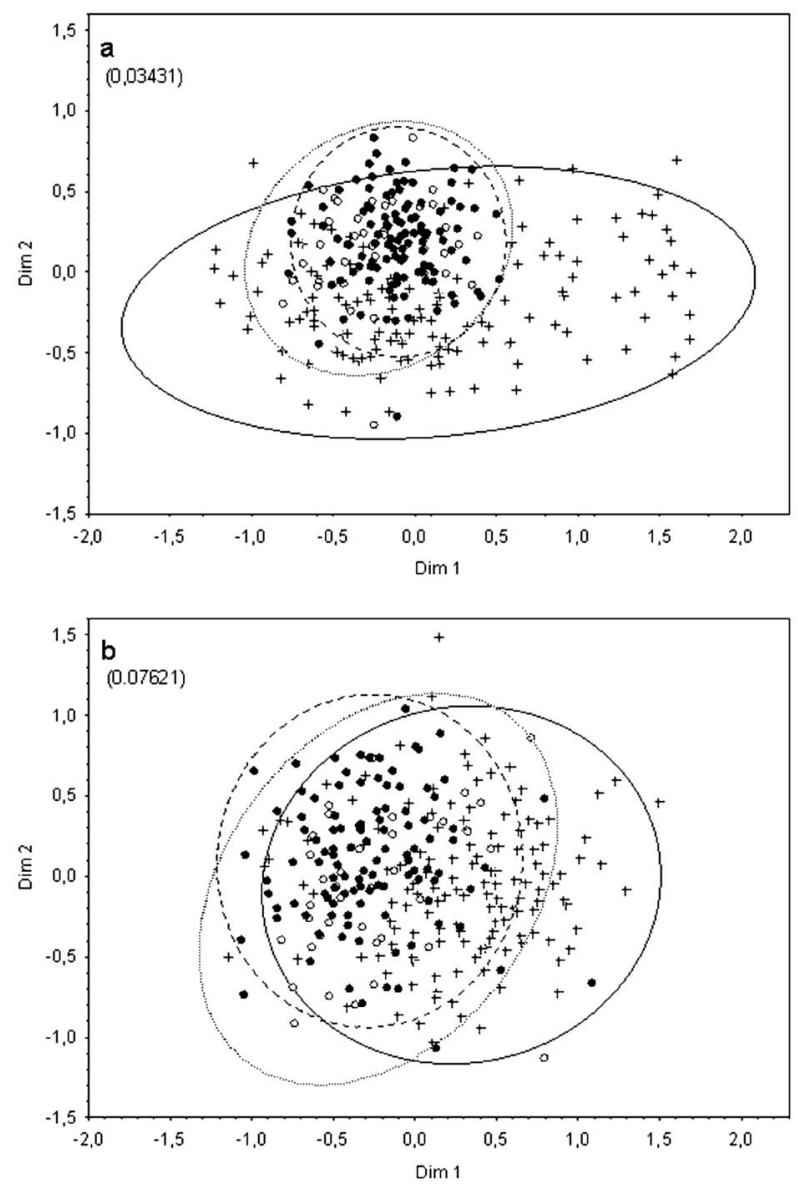

FIG. 3. - Non-metric multidimensional scaling (MDS) computed on shape variables (a) and allometry-free shape variables (b). Ellipses containing $95 \%$ of data are presented for each group. Stress values are between brackets and symbols are as in Figure 2.

\section{DISCUSSION}

Here we report a geometric morphometric study on the carapace shape of Cyrtograpsus affinis and $C$. altimanus that allows us to conclude that the former is a junior synonym of the latter. The study aimed to test for carapace shape differences between three different coastal regions, two of them within the Río de la Plata estuary and the third in the Nuevo Gulf (approximately $1150 \mathrm{~km}$ to the southwest). Previously we analyzed the regression between shape and size in order to test for shape allometry and to provide a graphical visualization of the relation between carapace shape of all the specimens included in the study and the graphical descriptions of the carapace used in previous morphological descriptions (Rathbun 1918, Spivak and Cuesta 2000).

The allometry in carapace shape was highly significant and the pattern of allometric shape variation precludes the existence of two morphologically dissimilar groups in the sample. The previous descriptions of the carapace shape of $C$. affinis and C. altimanus match different regions of a continuous allometric trajectory. The shape of the first instar of $C$. affinis previously described (Spivak and Cuesta 2000) matched with the smaller specimens ( 2 $\mathrm{mm}$ carapace width [CW]) captured in the Nuevo Gulf. The first descriptions of $C$. affinis and C. altimanus by Rathbun (1918) match with the allometric trajectory in the mid-region $(\sim 10 \mathrm{~mm}$ $\mathrm{CW})$ and in the extreme of the larger specimens ( 20 $\mathrm{mm} \mathrm{CW}$ ), respectively (Fig. 2). The relative position of previously described carapace shapes in a continuous allometric trajectory could be considered evidence supporting Spivak and Schubart's hypothesis that "the two forms represent different life stages of the same species". Several studies based on ontogeny (Guinot 1984 and Otani and Takahashi 1996) and genetics (Mantelatto et al. 2007) allowed two crab species originally described on the basis of juvenile or adult specimens, respectively, to be synonymized. Our work goes further in providing formal geometric morphometric tests aimed at detecting, quantifying and removing allometric effects on a sample of carapaces previously considered as belonging to two different species.

In traditional crustacean taxonomy, carapace shape was largely used and almost all geographic forms that could be separated (e.g. the absence of "linking forms", Mallet 2005) were assigned to a species rank. According to our results, the carapace shape of $C$. affinis is clearly affected by ontogenetic allometry. Furthermore, this is the main source of morphological variation and is possibly the cause of Rathbun's original taxonomic misclassification. Several authors highlight the taxonomic implications of ontogenetic allometry (Rincón 2000, Klingenberg et al. 2001, Rosas and Bastir 2004) 
and emphasize the need for a careful evaluation of the allometric effect when taxonomic assignation is focused on morphological variability. Shape allometry has also become important because of a trend towards using morphometrics also in the fields of conservation, biogeography, evolutionary biology (Santos Moreno and Hortelano 1997) and stock identification (Cadrin 2000, Chang and Hsu 2004).

Two different methods were used to compare carapace shape between geographic locations and yielded the same results: specimens from the Nuevo Gulf are different from those from the Río de la Plata estuary. Shape changes according to habitat variations have been recorded in other decapods species (Giri and Loy 2008, Barría et al. 2011). Organisms frequently develop specialized phenotypes adapted to local environmental conditions (Kingsolver et al. 2002) and the size-independent (allometry-free) morphological variation between locations may reflect local adaptation to contrasting habitats. The two locations sampled in this study are distinctive in the hydrographic conditions of the water masses. The sampling sites in the estuary are subtidal (10 and $13 \mathrm{~m}$ depth) and located 21 and 43 $\mathrm{km}$ from the nearest rocky intertidal, a muddy habitat with high turbidity, high temperature and low and variable salinity (Framiñan and Brown 1996, Guerrero et al. 1997); the sampling site in the Nuevo Gulf is also subtidal (15-20 m depth), but it is a near-shore $(<1 \mathrm{~km}$ from the shoreline) muddy bottom with lower temperature and turbidity, and higher salinity (Rivas and Ripa 1989). Also, both the estuary and the gulf have been classified into different zoogeographic provinces (the Argentinian and the Magellanic provinces, respectively), in which different communities are expected to occur (Balech 1954, Boschi 2000).

Differences in maximum body size have been mentioned as a partial source of morphological divergence among crab carapaces (Hopkins and Thurman 2010). The maximum size is consistently lower in specimens previously classified as $C$. affinis than in $C$. altimanus (Table 1 and Spivak and Schubart 2003). Furthermore, the size at maturity of females is lower in the former (see Spivak and Schubart 2003, Fig. 4). Intraspecific changes in size range and size at maturity of decapod crustaceans has been mainly related to latitude (e.g. Garth 1957, Hines 1989, Orensanz et al. 2007) but also to water quality (i.e. estuarine vs freshwater populations; Mashiko 2000), predation pressure and food availability (Hines 1989). These changes were generally considered to be the result of phenotypic plasticity rather than genetic differences. Recently, the dramatic differences within the two forms of adult squat-lobsters has been attributed to heterochronies leading to phenotypic plasticity and associated with a response of the species to a varying environment (Haye et al. 2010). The two successive life stages studied in this paper could be an excellent model for testing the hypothesis of heterochronic development as an explanation for the observed carapace shape differences, also testing whether one or several of the environmental features are associated with the observed phenotypic plasticity.

Morphometric research is more biologically meaningful if coupled with functional hypotheses regarding the adaptive significance of differences in body shape, a synthesis that is needed for the advancement of the field (Cadrin et al. 2005). The evidence of significant allometry of carapace shape found in this study highlights the need for a careful evaluation of the allometric effect when taxonomic assignation is focused on morphological variability. Furthermore, the geographic differences suggest an effect of the environmental variables on carapace shape, and a potential adaptive value of this trait. A fruitful line of research was developed in crab morphometrics when cheliped shape was related to habitat, especially in durophagous species (Silva et al. 2010 and references thereof). However, the link between the carapace shape and the environment conditions and epigenetic factors is poorly understood (Giri and Loy 2008, Barría et al. 2011). Studies manipulating habitat composition, predators and competitors will be required in order to test specific hypotheses and elucidate this association.

\section{REFERENCES}

Adams D. 1999. Methods for shape analysis of landmark data from articulated structures. Evol. Ecol. Res. 1: 959-970.

Aldrich J. 1993. The identification of biota through the analysis of their two-dimensional shapes, and the recognition of local forms in Carcinus maenas L. In: Aldrich J.C. (ed.), Quantified phenotypic responses in morphology and physiology. Ashford: JAPAGA, pp. 55-64

Anderson M. 2001. A new method for non-parametric multivariate analysis of variance. Austral Ecol. 26: 32-46.

Anderson M., Ford R., Feary D., Honeywill C. 2004. Quantitative measures of sedimentation in an estuarine system and its relationship with intertidal soft-sediment infauna. Mar. Ecol. Prog. Ser. 272: 33-48.

Balech E. 1954. División zoogeográfica del litoral sudamericano. Rev. Biol. Mar. 4(1-2-3): 184-195.

Barría E., Sepúlveda R., Jara C. 2011. Morphologic variation in Aegla (Decapoda: Reptantia: Aeglidae) from central-southern Chile: Interspecific differences, sexual dimorphism, and spatial segregation. J. Crustac. Biol. 31(2): 231-239.

Bookstein F. 1991. Morphometric tools for landmark data: geometry and biology. Cambridge University Press, Cambridge.

Bookstein F. 1996. Combining the tools of geometric morphometrics. In: Marcus L.F., Corti M., Loy A., Naylor G.J., Slice D.E. (eds.), Advances in Morphometrics. Plenum Press, pp. 131-151

Boschi E. 1964. Los crustáceos decápodos Brachyura del litoral bonaerense (R. Argentina). Bol. Inst. Biol. Mar. Mar de Plata 6: $1-100$.

Boschi E. 2000. Las especies de crustáceos decápodos y su distribución en las provincias zoogeográficas marinas americanas. Rev. Invest. Desarr. Pesq. 13: 1-136

Boschi E., Fischbach C., Dorio M. 1992. Catálogo ilustrado de los crustáceos estomatópodos y decápodos marinos de Argentina. Frente Marit. 10(A): 7-94.

Botello A., Alvarez F. 2006. Allometric growth in Creaseria morleyi (Creaser, 1936) (Decapoda: Palaemonidae), from the Yucatan peninsula, Mexico. Carribean J. Sci. 42(2): 171-179.

Brian J., Fernandes T., Ladle R., Todd P. 2006. Patterns of morphological and genetic variability in UK populations of the shore crab, Carcinus maenas Linnaeus, 1758 (Crustacea: Decapoda: Brachyura). J. Exp. Mar. Biol. Ecol. 329: 47-54.

Cadrin S. 2000. Advances in morphometric identification of fishery stocks. Rev. Fish. Biol. Fish. 10: 91-112.

Cadrin S., Friedland K., Waldman J. 2005. Stock Identification 
Methods: applications in fishery science. Elsevier Academic Press, Amsterdam.

Costa T., Soares-Gomes A. 2008. Relative growth of the fiddler crab Uca rapax (Smith) (Crustacea: Decapoda: Ocypodidae) in a tropical lagoon (Itaipu), Southeast Brazil. Pan-Am. J. Aquat. Sci. 3(2): 94-100.

Chang H., Hsu C. 2004. Statistical comparisons of some external morphometrical aspects of the swimming crab Protunus sanguinolentus (Herbst) populations inhabiting the Keelung shelf and Taiwan bank. TAO 15: 179-197.

Cheverud J. 1982. Relationships among ontogenetic, static, and evolutionary allometry. Am. J. Phys. Anthropol. 59: 139-149.

Daleo P., Luppi T., Mendez Casariego A., Escapa M., Ribeiro P., Silva P., Iribarne O. 2009. The effect of size and cheliped autotomy on sexual competition between males of the mud crab Cyrtograpsus angulatus Dana. Mar. Biol. 156(3): 269-275.

Drake A., Klingenberg C. 2008. The pace of morphological change: historical transformation of skull shape in St Bernard dogs. Proc. R. Soc., B. 275: 71-76.

Dryden I., Mardia K. 1998. Statistical Shape Analysis. Wiley, New York.

Framiñan M., Brown O. 1996. Study of the Río de la Plata turbidity front. Part I: spatial and temporal distribution. Cont. Shelf. Res. 16: $1259-1282$.

Garth J. 1957. Reports of the Lund University Chile Expedition 1948-49. 29. The Crustacea Brachyura of Chile. Lund. Univ. Arsskr. 53(7): 3-127.

Giberto D., Bremec C., Acha E., Mianzan H. 2004. Large-scale spatial patterns of benthic assemblages in the SW Atlantic: the Río de la Plata estuary and adjacent shelf waters. Est. Coast. Shelf. Sci. 61: 1-13.

Giri F., Loy A. 2008. Size and shape variation of two freshwater crabs in Argentinean Patagonia: The influence of sexual dimorphism, habitat, and species interactions. J. Crustac. Biol. 28(1): 37-45.

Good P. 2000. Permutation tests: a practical guide to resampling methods for testing hypotheses. Springer, New York.

Guerrero R., Acha E., Framiñan M., Lasta C. 1997. Physical oceanography of the Río de la Plata estuary, Argentina. Cont. Shelf. Res. 17: 727-742.

Guinot D. 1984. Le genre Leurocyclus Rathbun (Crustacea, Decapoda, Brachyura). Bull. Mus. Nat. Hist. Nat. 1(A): 211-247.

Gunz P., Mitteroecker P., Bookstein F. 2005. Semilandmarks in three dimensions. In: Slice D.E. (ed.), Modern Morphometrics in Physical Anthropology. Kluwer Academic, pp. 73-98

Haye P., Salinas P., Acuña E., Poulin E. 2010. Heterochronic phenotypic plasticity with lack of genetic differentiation in the southeastern Pacific squat lobster Pleuroncodes monodon. Evol. Devel. 12(6): 628-634.

Hines A. 1989. Geographic variation in size at maturity in brachyuran crabs. Bull. Mar. Sci. 45(2): 356-368.

Hopkins M., Thurman C. 2010. The geographic structure of morphological variation in eight species of fiddler crabs (Ocypodidae: genus $\mathrm{Uca}$ ) from the eastern United States and Mexico. Biol. J. Linn. Soc. 100: 248-270.

Hopkins M., Webster M. 2009. Ontogeny and geographic variation of a new species of the corynexochine trilobite zacanthopsis (Dyeran, Cambrian). J. Paleontol. 83(4): 524-547.

Huber M. 1985. Allometric growth of the carapace in Trapezia (Brachyura, Xanthidae). J. Crustac. Biol. 5(1): 79-83.

Huespe A., Gómez Simes E., Pastor de Ward C. 2008. Gastic mill morphology in the genus Cyrtograpsus (Crustacea: Decapoda: Grapsoidea: Varunidae). J. Mar. Biol. Assoc. UK 88(2): 311-319.

Huxley J. 1932. Problems of Relative Growth. The Dial Press, New York.

Kendall D. 1981. The statistics of shape. In: Barnett V. (ed.), Interpreting multivariate data. Wiley and Sons, pp. 75-80

Kendall D. 1984. Shape-manifolds, procrustean metrics and complex projective spaces. Bull. London Math. Soc. 16: 81-121.

Kent J. 1994. The complex Bingham distribution and shape analysis. J. R. Stat. Soc. 56(B): 285-299.

Kingsolver J., Pfenning D., Servedio M. 2002. Migration, local adaptation and the evolution of plasticity. Trends Ecol. Evol. 17: $540-541$

Klingenberg C. 1996. Multivariate allometry. In: Marcus L.F. (ed.), Advances in Morphometrics. Plenum Press, pp. 23-49

Klingenberg C. 2008. MorphoJ. Faculty of Life Sciences, Univer- sity of Manchester.

Klingenberg C. 2010. Evolution and development of shape: integrating quantitative approaches. Nature Rev. Gen. 11: 623-635.

Klingenberg C. 2011. MorphoJ: an integrated software package for geometric morphometrics. Mol. Ecol. Res. 11: 353-357.

Klingenberg C., Leamy L., Routman E., Cheverud J. 2001. Genetic architecture of mandible shape in mice: effects of quantitative trait loci analyzed by geometric morphometrics. Genetics 157 : 785-802.

Levin L. 2006. Recent progress in understanding larval dispersal: new directions and digressions. Integrative and Comparative Biology. 46(3): 282-297.

Mallet J. 2005. Speciation in the 21st century. Heredity 95: 105-109.

Mantelatto F., Robles R., Felder D. 2007. Molecular phylogeny of the western Atlantic species of the genus Portunus (Crustacea, Brachyura, Portunidae). Zool. J. Linn. Soc. 150: 211-220.

Martinetto P., Valiñas M., Palomo G., Iribarne O. 2007. Negative interactions between two SW Atlantic intertidal crabs in softbottom habitats. Mar. Biol. 151: 1479-1490.

Mashiko K. 2000. Insights into the mechanism of speciation in gammarid crustaceans of Lake Baikal using a population-genetic approach. Adv. Ecol. Res. 31: 221-235.

Méndez Casariego A., Alberti J., Luppi T., Iribarne O. 2008. Stagedependent interactions between intertidal crabs: from facilitation to predation. J. Mar. Biol. Ass. UK 89: 781-788.

Mouzo F., Garza M., Izquierdo J., Zibecchi R. 1978. Rasgos de la geología submarina del Golfo Nuevo (Chubut). Acta Oceanogr. Argentina 2: 69-91

Orensanz J., Ernst B., Armstrong D. 2007. Variation of female size and stage at maturity in snow crab (Chionoecetes opilio) (Brachyura: Majidae) from the eastern Bering sea. J. Crustac. Biol. 27(4): 576-591.

Orensanz J., Parma A., Iribarne O. 1991. Population dynamics and management of natural stocks. In: Shumway S.E. (ed.), Scallops: Biology, Ecology and Aquaculture. Elsevier, pp. 625-714

Osawa M., McLaughlin P. 2010. Annotated checklist of Anomuran Decapod Crustacean of the world (exclusive of the Kiwaoidea and families chirostylidae and galatheidae). Part II- Porcellanidae. Raffles Bull. Zool. 23: 109-129.

Otani T., Takahashi T. 1996. Cheliped transformation in the swimming pea crab Tritodynamia horvathi Nobili. Crustac. Res. 25: 137-141.

Parker G., Paterlini M., Violante M. 1997. El fondo marino. In: Boschi E.E. (ed.), El Mar Argentino y sus recursos pesqueros. Tomo 1. Instituto Nacional de Investigación y Desarrollo Pesquero, pp. 65-88

Perez S., Bernal V., Gonzalez P. 2006. Differences between sliding semi-landmark methods in geometric morphometrics, with an application to human craniofacial and dental variation. J. Anat. 208: 769-784.

Peters R. 1983. The Ecological Implications of Body size. Cambridge University Press, Cambridge.

Rathbun M.J. 1918. The Grapsoid crabs of America. Bull. U.S. Nat. Mus. 97: 1-461.

Rincón P. 2000. Big fish, small fish: still the same species. Lack of morphometric evidence of the existence of two sturgeon species in the Guadalquivir river. Mar. Biol. 136: 715-723.

Rivas A., Ripa P. 1989. Variación estacional de la estructura termohalina del golfo Nuevo, Argentina. Geofis. Int. 28(1): 3-23.

Rohlf F. 1993. Relative warp analysis and an example application to mosquito wings. In: Marcus L.F., Bello E., García-Valdecasas A. (eds.), Contribution to Morphometrics. CSIC, pp. 131-159

Rohlf F. 1996. Morphometric spaces, shape components and the effects of linear transformations. In: Marcus L.F., Corti M., Loy A., Naylor G.J.P., Slice D.E. (eds.), Advances in morphometrics. Plenum Press, pp. 117-129

Rohlf F. 1998. TpsSmall, versión 1.15. Stony Brook, NY: Department of Ecology and Evolution, State University of New York at Stony Brook.

Rohlf F. 1999. Shape statistics: Procrustes superimpositions and tangent spaces. J. Classif. 16: 197-223.

Rohlf F. 2004a. TpsDig, version 1.39. Stony Brook, NY: Department of Ecology and Evolution, State University of New York at Stony Brook.

Rohlf F. 2004b. TpsRelw, version 1.35. Stony Brook, NY: Department of Ecology and Evolution, State University of New York at Stony Brook. 
Rohlf F. 2004c. TpsUtil, version 1.26. Stony Brook, NY: Department of Ecology and Evolution, State University of New York at Stony Brook.

Rohlf F., Bookstein F. 1987. A comment on shearing as a method for "size correction". Syst. Zool. 36: 356-367.

Rohlf F., Marcus L. 1993. A revolution in morphometrics. Trends Ecol. Evol. 8: 129-132.

Rohlf F., Slice D. 1990. Extensions of the Procrustes method for the optimal superimposition of landmarks. Syst. Zool. 39: 40-59.

Rosas A., Bastir M. 2004. Geometric morphometric analysis of allometric variation in mandibular morphology from the hominids of Atapuerca, Sima de los Huesos site. Anat. Rec. 278(A): 551-560.

Rufino M., Abelló P., Yule A. 2006. Geographic and gender shape differences in the carapace of Liocarcinus depurator (Brachyura: Portunidae) using geometric morphometrics and the influence of a digitizing method. J. Zool. 269: 458-465.

Santana W. Tavares M. 2010. Temnonotus simplex A. MilneEdwards, 1875, a junior synonym of Temnonotus granulosus A. Milne-Edwards, 1875 (Decapoda: Brachyura: Majidae) Nauplius 18(2): 147-152.

Santos Moreno J., Hortelano Y. 1997. La variación en mamíferos: una revisión de los enfoques metodológicos actuales. Acta Zool. Mexic. 70: 13-34.

Sardà F., Company J., Costa C. 2005. A morphological approach for relating decapod crustacean cephalothorax shape with distribution in the water column. Mar. Biol. 147: 611-618.

Schubart C., Cuesta J., Diesel R., Felder D. 2000. Molecular phylogeny, taxonomy, and evolution of non-marine lineages within the American Grapsoidea (Crustacea: Brachyura). Mol. Phylogenet. Evol. 15: 179-190.

Schubart C., Cuesta J., Felder D. 2002. Glyptograpsidae, a new brachyuran family from Central America: larval and adult morphology, and a molecular phylogeny of the Grapsoidea. $J$. Crustac. Biol. 22: 28-44.

Sheets H., Covino K., Panasiewicz J., Morris S. 2006. Comparison of geometric morphometric outline methods in the discrimination of age-related differences in feather shape. Front. Zool. 3 : $1-12$.
Silva A., Silva I., Haukins S., Boaventura D., Thompson R. 2010. Cheliped morphological variation of the intertidal crab Eriphia verrucosa across shores of differing exposure to wave action. $J$. Exp. Mar. Biol. Ecol. 391: 84-91.

Silva P. 2009. Biología reproductiva de tres especies de cangrejos Brachyura a lo largo de un gradiente marino-estuarial. Doctoral thesis, Universidad Nacional de Mar del Plata. $173 \mathrm{pp}$

Slice D. 2001. Landmark coordinates aligned by procrustes analysis do not lie in Kendall's shape space. Syst. Biol. 50(1): 141-149.

Sneath P. 1967. Trend-surface analysis of transformation grids. $J$. Zool. 151: 65-122.

Sokal R., Rohlf F. 1995. Biometry; the principles and practice of statistics in biological research. Freeman and Company, New York.

Spivak E. 1997. Cangrejos estuariales del Atlántico sudoccidental $\left(25^{\circ}-41^{\circ} \mathrm{S}\right)$ (Crustacea: Decapoda: Brachyura). Invest. Mar. 25: 105-120.

Spivak E. 1999. Effects of reduced salinity on juvenile growth of two co-occurring congeneric grapsid crabs. Mar. Biol. 134: 249-257.

Spivak E., Cuesta J. 2000. Larval development of Cyrtograpsus affinis (Dana) (Decapoda, Brachyura, Varunidae) from Río de la Plata estuary, reared in the laboratory. Sci. Mar. 64: 29-47.

Spivak E., Schubart C. 2003. Species status in question: a morphometrics and molecular comparison of Cyrtograpsus affinis and C. altimanus (Decapoda, Brachyura, Varunidae). J. Crustac. Biol. 23(1): 212-222.

Teissier G. 1960. Relative growth. In: Waterman T. (ed.), The Physiology of Crustacea. Academic Press, pp. 537-560

Tracey S., Lyle J., Duhamel G. 2006. Application of elliptical Fourier analysis of otolith form as a tool for stock identification. Fish. Res. 77: 138-147.

Webber A., Hunda B. 2007. Quantitatively comparing morphological trends to environment in the fossil records (Cincinnatian Series, Upper Ordovician). Evolution 61(6): 1455-1465.

Scient. ed: K. Anger.

Received April 7, 2011. Accepted October 18, 2011.

Published online February 16, 2012. 